\title{
THE ROLE OF GENDER POLICY IN TURKISH VET SYSTEM
}

\begin{abstract}
The article examines the evolution of gender policies in the field of vocational education in Turkey since the beginning of the $20^{\text {th }}$ century up to the present. Schools for girls started to emerge in Turkey at the beginning of the republican era. Their aim was to teach students about gender roles consistent with the trend of modernization and westernization of the new Turkish state. The ideology of a modern conservative party ruling in the Republic of Turkey is based on the traditional role of women as home keepers, while the country's legislative system undergoes changes that provide women with independency. This policy is full of contradictions, namely, changes in legislation are aimed at improving education and employment of women, while women are encouraged to remain housewives. Despite the fact that women received equal rights to education after the Law on Unification of Education was adopted in 1924, gender inequality is still an issue in modern Turkish society. There is a strong legal framework at the state level and executive authorities that provide girls and women with free access to education and promote learning. Statistical data show that the education system still has many unresolved issues concerning the learning opportunities of girls and their employment. According to recent statistics, a very small group of girls goes on to secondary education in the Republic of Turkey. In 2011, only $24 \%$ of girls completed their secondary education that is the lowest level in the countries of OESD. Amazingly low percentage of girls involved in secondary education system can be explained by two objective factors: socioeconomic status of girls' families and gender discrimination. Vocational schools for girls are designed to resolve this issue.

Keywords: gender education, gender policy, gender inequality, women's education, vocational education, Turkey.
\end{abstract}

\section{INTRODUCTION}

Nowadays, building a democratic society and ensuring its existence are impossible without equal respect for interests and opportunities of both men and women. The basis for gender equality is education, which should not merely stipulate gender stratification of society, but rather promote gender equality. As noted in the World Declaration on Higher Education for the 21st Century: Vision and Action (Paris, October 9, 1998), "education should eradicate stereotypes caused by gender, consider gender aspects in all disciplines, expand women's participation in all disciplines and at all levels they are underrepresented, ensure their involvement in decision-making" (1998, p. 7).

\section{THE AIM OF THE STUDY}

The aim of the study is to outline the main gender problems of modern vocational education in Turkey.

\section{THEORETICAL FRAMEWORK AND RESEARCH METHODS}

Over the past 20 years, many scholars have studied the impact of education on society genderization. In particular, M. Kimmel (2003) said, "education institutions resemble old factories and they produce engendered individuals" (p. 232). O. Yarska-Smirnova 
and V. Yarskaya (2002) have studied gender socialization in education and hidden curriculum. L. M. Stenstrem has conducted researches on gender stratification in vocational education. Gender issues of curriculum for vocational education in education institutions of Latin America have been covered by C. Fawcett and S. Houden. D. Dzhyndohlu, F. Hok, S. Toktash have analyzed the history of vocational education and training (VET) of women in the Republic of Turkey. E. Demiray has covered the problems of women's education in Turkey.

In our article, we have used the methods of analysis of statistical data and methods of comparison.

\section{RESULTS}

After the establishment of the Republic of Turkey in 1923, the Turkish government launched a number of legal, educational and social reforms aimed at rapid modernization and urbanization. The newly-formed state's goal was to build a modern society in accordance with the Western lifestyle. The Kemalist reforms meant a new attitude of the state towards women's positions and rights.

Kemalizm is a worldview often related to the reforms conducted by Mustafa Kemal Ataturk. According to it, women, housewives and mothers who bring up future generations of citizens in compliance with the ideals of the state have to spread the values of the Republic and to build a modern family. Republican gender ideology entrusted women with the mission of showing to the rest of the world a new image of Muslim women - educated and active in public life. However, the position of women who did not belong to the Turkish elite had not changed. It had to be improved by vocational education for girls in so-called institutes for girls (vocational lyceums later on).

Schools for girls started to emerge in Turkey at the beginning of the republican era. Their goal was to teach them gender roles consistent with the trends of modernization and westernization of the new Turkish state. As the historical analysis shows these schools improved and developed with the changes occurring in Turkish society and public policy (Toktas \& Cindoglu, 2006). They slowly evolved from ordinary schools training "good housewives" to vocational schools (Toktas \& Cindoglu, 2006). At the same time, women's gender roles and their employment opportunities in the labour market had been revised.

The ideology of a modern conservative party ruling in Turkey is based on the traditional role of women as home keepers, while the state held legislative changes that provide women with the status of independent citizens. Such policy is full of contradictions, namely, changes in legislation are aimed at improving education and employment of women, while women are still encouraged to remain housewives (Toktas \& Cindoglu, 2006).

Despite the fact that women received equal rights to education after the Law on Unification of Education was adopted in 1924, gender inequality is still an issue in modern Turkish society (Demiray, 2015).

The Global Gender Gap Report published annually by the World Economic Forum assesses 134 countries in terms of rights and freedoms of women and shows the regression in the case of gender inequality. In the 2016 Ranking, Turkey is the $130^{\text {th }}$ among 134 countries as for the equality of women and men. Concerning women's equal access to education, Turkey occupies the $109^{\text {th }}$ place (World Economic Forum, 2016).

There are all legal backgrounds for ensuring gender equality in Turkey. The Constitution adopted in 1982 guarantees education for all people without exception in (Article 42), "primary education is compulsory for all citizens of both sexes and is free in public schools". Accordingly, all the legal mechanisms, such as laws, legislation and regulations cover the whole society regardless of gender (Demiray, 2015). In Article 4 of 
the Basic Law on National Education it is stated that "schools are open for all citizens, irrespective of language, race, religion or gender". In Article 8 it is indicated about "equality of opportunities, offered to all women and men in education". In Article 2 of the Law on Primary Education it is stated that "primary education is compulsory for girls and boys of school age and is free in public schools" (Demiray, 2015, p. 3).

The Turkish government delayed the process of gender equality institutionalization. In many European countries, this process took place in 1970, but in Turkey it was launched only in 1987 with the emergence of the Advisory Committee on Policy on Women within the Main Directorate of Social Planning (Demiray, 2015). The Convention on Elimination of All Forms of Discrimination against Women and the Sixth Five-Year development plan required an executive or coordinating unit on women to be established. Therefore, the 422 Law as of April 20, 1990, proclaimed the creation of the Main Department on the Position and Problems of women (Demiray, 2015). The Department develops various projects on gender policy, which are financially supported by various international organizations. Thus, there is a strong legal framework and enforcement authorities designed to provide girls and women with free access to education and promote learning at the state level. Statistical data show that there are still many unresolved issues concerning girls' learning opportunities and their employment in the education system.

According to recent statistics, the impressive number of Turkish girls does not continue their studies after primary school. In 2011, only $24 \%$ of girls completed their secondary education. It is the lowest level in the OESD countries (UNESCO, 2012). Despite the fact that the situation with boys is also disappointing as only $35 \%$ of boys completed secondary education, the disproportion of ratio between girls and boys is not only the largest among the OESD but in the whole Central Asia and European regions.

Significantly low percentage of girls' involvement in secondary education can be explained by two objective factors, namely, socioeconomic status of girls' families and gender discrimination (Uçan, 2013).

The Turkish education system reproduces stereotypes about the roles of men and women in Turkish society, and these roles influence boys and girls' choice of education and profession. Girls tend to choose general and vocational programs, which will help them to find women's work. As research findings show, girls' families affect their choice during final years of high school. At the university level, girls prefer humanities, while boys choose technical professions (Demiray, 2015).

In addition, boys generally occupy more privileged positions than girls in family due to traditionally patriarchal Turkish society. Therefore, families with limited economic resources who live in rural areas keep girls at home for various domestic and agricultural works and send boys to school (Demiray, 2015).

Because of the small number of girls who completed secondary education, fewer young women have necessary knowledge and skills needed for work in the non-agricultural sector (Uçan, 2013).

Employment and vocational training of women have rather disappointing trends toward gender inequality in Turkey, which is reflected in low rates of girls' enrolment in secondary education, namely, 64 percent of girls versus 75 percent of boys and significantly low levels of women's participation in the labour market - 29 percent (Demiray, 2015). Thus, vocational training of women in Turkey has recently become a real issue for social policy, as two topics of fierce debates on gender policy cross, i.e., attracting more girls to secondary education and employment of women. 
Vocational schools for girls are called to solve this problem. However, the quality of education in these schools could be better. The relationship between vocational education and the labour market and, more importantly, its role in representing the labour force divided by gender and a traditional structure of families remains questionable.

The Turkish government issued a report where it is stated that graduates from these schools show worse results while transferring from school to work or higher education compared with the girls who attend other vocational schools (Uçan, 2013).

Researchers point out that the priority given to vocational education in order to increase the rates of girls' involvement in secondary education and the labour force can lead to an increase in gender inequality. Moreover, the role of vocational education in strengthening the connection between training and social stratification is ignored (Demiray, 2015).

In secondary schools girls are prepared for the labour market and admission to universities as well as secondary education institutions related to vocational education (Uçan, 2013; World Atlas of Gender Equality in Education, 2012). According to the UNESCO (2012), only $24 \%$ of women have non-agricultural occupations.

However, there is a positive side of attracting girls to vocational education. In the developing countries like Turkey facilitation of girls' access to secondary education has a crucial significance for development of skilled labour force that can support sustainable economic growth (Uçan, 2013).

Teenage girls who obtained secondary education have more chances of obtaining employment. It means that encouraging girls to receive secondary education automatically reduces the unemployment level and promotes middle-class prosperity (UNESCO, 2012). In addition, in the 2011 Education for All Global Monitoring Report it is stated that there is proven link between the level of women's education and their children's health (Uçan, 2013). Educated mothers raise more healthy children than mothers with low levels of education (Uçan, 2013).

The Turkish government headed by the justice and development party (AKP) undertook to attract the greater number of students to secondary education and eliminate gender inequality in secondary education (Uçan, 2013).

However, political and civil opponents of the amendment are concerned that a suggested reform may have negative consequences. It might increase gender inequality and cause lower educational achievements of girls (ERI, 2012; Uçan, 2013).

Thus, within the Nine-Year Development Plan for 2007-2013, the Turkish government had set a goal to achieve socioeconomic balance throughout the country by stimulating economic growth and equipping its citizens with the skills necessary for successful participation in the global economy (ERI, 2012; Uçan, 2013).

For this purpose, the last year's amendment to the 4306 Law was adopted. It consolidated compulsory education, extended the duration of compulsory education from eight to twelve years "to improve educational attainment in Turkey" (Uçan, 2013, p. 17).

Turkey's new plan " $4+4+4$ " allows pupils to start vocational education after primary school. Before the reform, children had to study for eight years at secondary school before they gained an opportunity to enter high school or vocational school (UNESCO, 2012; World Bank, 2005). Compulsory education is divided into three stages being four years each: primary school (grades 1-4) and secondary school, which includes intermediate classes (grades 5-8) and high school (grades 9-12) (Uçan, 2013). According to this amendment, pupils who completed primary school have the opportunity to enter secondary or vocational school. Pupils of vocational schools have an additional opportunity to attend 
religious Imam-Khatib schools that also belong to the system of vocational education (Uçan, 2013).

It is assumed that the reform primarily aimed at improving access to secondary education for families, which live in rural areas and traditionally do not have enough money to send children to school. Such families often do not send daughters to school or take them at the end of secondary school. However, as already noted, many citizens and political opposition to the AKP is particularly concerned about a new structure of expanded compulsory education. The main controversial point is the conditions that allow attending Imam-Khatib schools immediately after primary school (Uçan, 2013).

In addition, there is a concern that Turkey currently has no infrastructure needed to implement reforms that require a significant increase in the number of secondary schools and universities nationally (ERI, 2012). Many scholars and teachers in Turkey believe that the shift to vocational training will cause a decrease in professional knowledge and skills of workers, create a market of low-skilled labour and hinder the ability of the nation to maintain its economic growth (Uçan, 2013).

The experience of many countries with compulsory secondary education shows that the most effective models of education are those that increase duration of general secondary education. Countries that have benefited from such an increase are the members of the European Union (EU), namely, Finland and Poland.

Although Turkey is very different from Finland and Poland culturally, such a comparison may be appropriate for two reasons: first, as Finland and Poland, Turkey followed the Prussian education system (Demiray, 2015). So, it is advisable to explore the education systems of those countries, which have the same foundation and became one of the best in the world. Secondly, Turkey continues to make a claim for EU membership, despite recent statements of President Erdogan.

Despite the different conditions in the labour market and active position of women in the labour force, the situation mentioned above shows the parallels between the political debates in Turkey and EU on gender equality policy in employment. Social policy of Turkey and recent debates in Europe clearly show that gender regimes act like controllers that promote policies compatible with the views on gender roles inherent in this culture. Conditional cash transfers have helped countless families around the world to send their daughters to school. Some of these programs such as the Conditional Cash Transfers Initiative of Turkey in partnership with the World Bank are specifically aimed at secondary school girls. These programs have achieved significant results.

Unfortunately, the Turkish education system still has many problems that require immediate solution, namely, a large share of those who graduate early $(53,4 \%)$ and especially girls; low percentage of employed women in the labour market; high percentage of illiterate population $(12,5 \%)$ where women make up more than $20 \%$, etc.

\section{CONCLUSIONS}

Statistics shows that building society where girls receive a comprehensive general education promotes a healthy, wealthy, stable society. If the girls in Turkey receive a solid foundation of knowledge and skills in the course of eight years in secondary school, they will be able to develop strong analytical and critical thinking skills. This will increase the number of educated women who will join the ranks of skilled labour. The more educated women, the lower the unemployment rate and the more stable and healthier the society is.

In general, researchers think that the policy under which compulsory education will be extended to twelve years of training and the structural component will change have more positive effects than negative. 
The introduction in 2013 of a new curriculum on the scheme $4+4+4$ according to its creators will make secondary education more accessible for girls from rural regions and poor families. The task of further research is to show how effective this plan is.

\section{REFERENCES}

1. Demiray, E. (2015). Problems in women's education in Turkey. Implementations and suggested solutions. International Journal on New Trends in Education and Their Implications, 6 (1), 1-12.

2. Education Reform Initiative (ERI). (2012). Education Reform Initiative. $4+4<8$ : The proposed bill lowers compulsory education to four years. Istanbul: Sabanci University.

3. Kimmel, M. (2003). Genderovane suspilstvo. Kyiv: Sfera.

4. Toktas, S., \& Cindoglu, D. ( 2006). Modernization and gender: a history of girls' technical education in Turkey since 1927. Women's history review, 15 (5), 737-749.

5. Uçan, E. (2013, January 24). Increasing Inclusion of Girls in Secondary Education in Turkey. Harvard University Graduate School of Education, Global Education Leadership Opportunities Conference, p. 1

6. UNESCO. (2012). World Atlas of Gender Equality in Education. Retrieved from http://www.uis.unesco.org/Education/Documents/unesco-world-atlas-gender-education-2012.pdf

7. Vsemirnaya Deklaratsiya o vyisshem obrazovanii dlya XXI veka: podhodyi $i$ prakticheskie meryi (Paris, October 9, 1998). Retrieved from http://www.sde.ru/files/t/pdf/5.pdf.

8. World Bank. (2005). Turkey - education sector study: sustainable pathways to an effective, equitable and efficient education system for preschool through secondary school education. Retrieved from https://openknowledge.worldbank.org/ handle/10986/8393.

9. World Economic Forum. (2016). The global gender gap report. Retrieved from http://www3.weforum.org/docs/GGGR16/WEF Global Gender Gap Report 2016.pdf.

10. Yarskaya-Smirnova, Ye. P., \& Yarskaya, V. N. (2002). "Ne muzhskoye eto delo ...". Gendernyiy analiz zanyatosti v sotsialnoy sfere. Sotsiologicheskie issledovaniya, $6,74-83$. 